\title{
ФУНКЦІОНАЛЬНО-СТИЛІСТИЧНІ ОСОБЛИВОСТІ ПОВТОРУ В ПОЕТИЧНИХ ТЕКСТАХ КІНЦЯ ХХ - ПОЧАТКУ ХХІ СТОЛІТТЯ
}

Ріжко Р. Л. Функціонально-стилістичні особливості повтору в поетичних текстах кінця XX - початку XXI століття.

Статтю присвячено повтору як одній із лінгводомінант поетичної мови кінця $\mathrm{XX}$ - початку XXI століття, звернено увагу на його «співдію» 3 іншими стрижневими стилістичними одиницями. Визначено функціональне навантаження повтору в українській мовотворчості задекларованого періоду.

Ключові слова: поетичний текст, повтор, анафора, епіфора, анепіфора, градація, ампліфікація.

Рижко Р.Л. Функционально-стилистические особенности повтора в поэтических текстах конца XX - начала XXI века.

Статья посвящена повтору как одной из лингводоминант поэтического языка конца XX - начала XXI века, обращено внимание на его «сотрудничество» с другими стержневыми стилистическими единицами. Определено функциональную нагрузку повтора в украинском языкотворчестве задекларированного периода.

Ключевые слова: поэтический текст, повтор, анафора, эпифора, анепифора, градация, амплификация.

Rizhko R. L. Functional-stylistic features of the repeat in the poetic texts of the late XX - early XXI century.

The article is devoted to the repeat as one of the dominant the of poetic language of the late XX - early XXI century. The attention is drawn to its «necessary assistance» from the other basic stylistic units. The author has analyzed the function of the repeat in the Ukrainian poetic texts of the specified period.

Key words: poetic text, repeat, anaphora, epiphora, anepifora, gradation, amplification.

Функціональна антропозорієнтована парадигма сучасної лінгвістики актуалізує увагу на дослідженні мови художніх текстів, що передусім репрезентує індивідуально-авторську картину світу 3 вербальною маніфестацією морально-етичних цінностей, світосприйняття кожного 3 майстрів слова. Важливим у лінгвостилістиці $€$ аналіз домінантних лінгвоодиниць, їхнього функціонального навантаження, наукова інтерпретація авторської художньої моделі світу, виявлення особливостей трансформації мовних явищ у системі художньо-образного бачення митців тощо.

Так, одним із стрижневих складників поетичної мовотворчості кінця XX - початку XXI століття є повтор. Це стилістична фігура, що формується сукупністю однорідних дво- чи багаторазово 
відтворюваних мовних одиниць (звуків, складів, слів, словосполучень, речень) у межах тексту чи його сегмента, виступаючи засобом образой текстотворення, результатом і умовою реалізації індивідуальноавторської поетичної картини світу.

Мета нашого дослідження - розкрити функціональне навантаження повтору в поетичній мові кінця XX - початку XXI століття.

Як показав аналіз фактичного матеріалу, повтор, «співпрацюючи» 3 іншими стилістичними одиницями (анафора, епіфора, анепіфора, паліндром, паронімічна атракція, монафони, епаналепсис, градаџія, ампліфікаџія, тавтологія, полісиндетон, рефрен тощо), комплектує макро- та мікрообрази, лейтмотиви не тільки на предметному (денотативному) значенні слів, а передусім на імплікаційному, актуалізуючи авторські інтенції та спроектовуючи увагу реципієнта на «правильне», умотивоване в поезії, семантичне дешифрування тексту.

Повтор сприяє формуванню структурної i семантичної цілісності тексту, його синкретичності, тобто виконує стратифікаційно-когерентну функцію. Наприклад: $\boldsymbol{T e}$, щзо мудро $\check{u}$ гарно у природi, - / Te в людині, мій синочку, - страшно (І. Жиленко); Tym ніч $і$ дощ. Tym холодно тепер. / Tym листя падає обличчям на обличчя. / Tym вітер із нічних глухих озер / У двері двічі стукає, як тричі (Т. Федюк); Ріко моя, не клич сестрою Лету. / Ріко моя, верни ім'я мені... (Р. Скиба); Бери мене, доле, не бійся, / Бери мене, щзастя крилате, / Бери мене, болю незнаний... (М. Людкевич) [101, с. 26]; я хочу їхати у річковому трамваї, / я хочу тримати у лівій кишені чиєсь кришталеве серце (О.Стернічук); Ворожили коні на снігу, / ворожили коні дуже просто. У пелюстиі снігу розгребли / призабуту осінь (Л. Малкович) та ін. Як бачимо, анафора (єдинопочаток), крім того, що структурно організовує текст, ще й вносить у вислів нові художньо-образні відтінки. Завдяки анафоричному повтору збільшується семантичний обсяг мовних одиниць.

Зазначимо, що повторюваними в досліджуваних текстах є слова різної частиномовної належності. Вони конденсують авторську думку, служать основою різних образних уявлень, підсилюючи емоційне сприйняття твору.

Зупинимося детальніше на особливостях анафоричних прикметників у семантичному контексті. Так, матеріал поезії засвідчує, що кольорова гама, значеннєво закладена в атрибутивних 
формах, витворює свої неповторні мотиви, актуалізує нові обертони смислів: У синьому морі я висіяв сни, / У синьому морі на синьому глеї / Я висіяв сни із твоєї весни, / У синьому морі з весни із твоєї (М. Вінграновський); Зелен ліс, зелен гай, / Зелен бір-дідуган, / Зелен дуб-сонцелюб, / Зелена травичка, / На траві -лисичка (А. Мойсієнко). Лексеми синій та зелений мають «широке тлумачення позитивної оцінки: легкий, ніжний, добрий, лагідний» [4, с. 346], реальне предметно-візуальне значення кольору; називаючи усталену фарбу природи, набувають у тексті символічного змісту оновлення життя, молодості, свіжості, сили, надії та радості.

Стилістично виразними $є$ випадки використання повтору множинних форм займенників ми (авторське «я» вжите як засіб зближення поета 3 читачем), ви (вказує на багатьох осіб, до кого звернена мова). Займенники зазвичай протиставляються іншим частинам мови як слова, що не мають власного лексичного значення, однак у поетичній мовотворчості особові займенники субстантивуються (входять до складу нових референційних рядів, нових комунікативних ситуацій), виступаючи важливим чинником образо- і текстотворення. Доречно також сфокусувати увагу на вживання паліндромів («слово, фраза, фрагмент вірша або вірш, які читаються однаково зліва направо та справа наліво» [5, с. 527]) та паронімічної атракції, яка в досліджуваних текстах широко представлена консонантним типом (грунтується на консонантному розподібненні «основ», що супроводжується тотожними голосними)

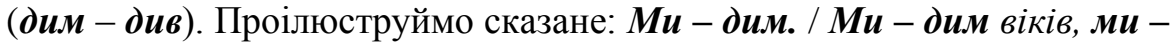
дим. / Ми - дим низин, ми - дим / Ми долом молодим. / Ви - димами див. / Ви дущу димами, дущу див. / Ви - ууху за пазуху див. / Ми - уух $\boldsymbol{y} \partial \boldsymbol{u} \boldsymbol{м}$ (А. Мойсієнко).

Домінантним у наведеному фрагменті є творення образів не тільки на денотативному значенні слів, а передусім - на їх звучанні, зумовлене «співдією» паронімічної атракції та окремих звукових повторів. Можна стверджувати, що повтор $є$ «не лише засобом, а «необхідною (хоч і недостатньою) умовою зв’язності тексту». Він бере участь у здійсненні локальної (зв'язність лінійних послідовностей у тексті) та глобальної зв'язності (те, що забезпечує єдність тексту як цілого, його внутрішню цілісність)» [6, с. 56].

Близькою за семантикою до анафори і водночас протилежною їй щодо синтаксичної будови виступає епіфора (єдинокінцівка), яка забезпечує цілісне звукове тло всієї ліричної поезії. Наприклад: Збирачі 
легенд і міфрів - / поміж вивітрених румовищ сну. / Черлений $і$ чорний / на білому / і то тільки на білому. / Іти на голос, / як важко йти лише / на голос. / Голос - черлений і чорний / на білому / i то тільки на білому (О. Жупанський).

Отже, контрастну характеристику образів у текстовому сегменті створюють антонімічні лінгвоодиниці. Повніше розкриваючи складність та суперечність зображуваних явищ, вони формують відповідну інтонацію, настрій твору. Так, черлений (червоний) i чорний - символи трагічного життя (червоний асоціюється 3 небезпекою, кров'ю, війною [1, с. 35-36], чорний - злом, нещастям, скорботою, трауром, смертю і потойбічним життям [1, с. 37]), у контексті контрастують із білим (символ добра, чистоти, божественності, святості, життя [1, с. 33]) - світлим променем людської душі. Кольоратив червоний переважно $є$ багатозначним та амбівалентним символом (колір життя, енергіі, сонця, вогню; пристрасті, любові, радості, агресивності, гніву [1, с. 35]), проте в наведеному контексті разом із чорним виступає негативним експресивно-аксіологічним маркером.

Матеріал нашого дослідження дає підстави стверджувати, що, крім наведених видів повтору, стратифікаційно-когерентну функцію в поетичних текстах кінця XX - початку XXI століття реалізує також анепіфора.

Анепіфора (анаепіфора), або кільце строфи, - стилістична фігура, що поєднує в собі анафору та епіфору: повторення однакових елементів на початку i в кінці кількох паралельних відрізків висловлення 3 різною серединою [3, с. 52]. Анепіфора сприяє композиційній стрункості та завершеності тексту, підсилює його основну думку: Несу тобі передчуття снісів, / I білим холодом зелена пахне м'ята. / Некликана, нелюблена, не клята - / Несу тобі передчуття снісів (Л. Голота); Яка зелена тиша навкруги! / Довкіл n'янке липневе різнотрав'я. / I поплавка стрімкого завмирання / На плесі, щуо в хустині з окуги. / Тут плине час привільно, без снаги / Стежиною від хати на помості. / Дрімає серие у солодкій млості. I Яка зелена тиша навкруги! (В. Калашник). У поєднанні 3 абстрактним іменником кольоративний прикметник зелений виражає позитивно-емоційну аксіологічну характеристику стану душі ліричного героя, передає відчуття легкості, безтурботності, ніжності. Домінантним у цьому тексті є зв'язок із когнітивним прототипом лексеми зелений - рослинним світом. 
У досліджуваній поетичній мовотворчості, крім стратифікаційно-когерентної, повтор виконує емоційно-експресивну функцію - сприяє підсиленню й увиразненню, виділенню певних складників тексту або й усього висловленого в ньому (відзначимо, що функції цієї стилістичної фігури виділено умовно, оскільки в художньому тексті вони взаємодіють, доповнюючи одна одну). Так, повтор формує основний лейтмотив тексту, концентруючи увагу на його провідній думці. Наприклад: Моя любов - закінчений антракт розіп'ятих крил / моя віра - брутальна пляма роздягненої святости / моя правда - молитовна заздрість (М. Бриних); все, щзо не описати пером, / навіть просяклим чорним Дніпром, / жести вберуть без скорочень - / наші арійські гоп-гопаки, / наші варязькі забави, / наше із вивертом «навпаки», / наші найтяжчі дяки-літаки, / наші найвищі заграви... (В. Неборак) тощо.

Як бачимо, основне комунікативне навантаження у поетичних фрагментах містять повторювані займенники, конкретизуючи семантичне наповнення висловлювань автора у рецепції сприймача інформації (читача). Можна стверджувати, що вживання присвійних займенників мій, наш необхідне для фокусування уваги на предметі розмови, що сприяє підсиленню інтересу до змісту основного повідомлення. Завдяки повтору лексичні одиниці художньо увиразнюються, надаючи висловлюванню відповідної емоційної та експресивної наснаженості, що досягається за рахунок взаємодії лексичних і синтаксичних засобів.

Розкриття особливостей функціонування поетичної лексики кінця XX - початку XXI століття засвідчує, що експресивний, образно-стилістичний ефект висловлення зростає при взаємодії повтору з градацією. Ця фігура полягає в поступовому нагнітанні засобів художньої виразності для підвищення їхньої емоційносмислової значущості. 3 огляду на це розрізняють градацію висхідну (Тож нехай там загрози і грози, / I нехай же сутужно в Макао, / Поєднали і радість, і сльози / I цитрина, і біб, і какао! (Ю. Позаяк) та спадну (I чорної райдуги біле тіло / I чорні очі, як сто кринцць. / I чорної райдуги небо згоріло, / I райдуга впала на землю ниць (М. Вінграновський) (прикметник чорний та іменник райдуга перебувають між собою в граматичному підпорядкуванні, утворюючи змістову парадоксальну єдність - оксиморон); I перший сніг, i син, останній иввіт... / Переболіло, відболіло, звогкло (І. Павлюк). Обидва типи градації в аналізованих текстах виконують функції як логічної, 
так і емоційної домінанти.

Матеріал нашого дослідження показує, що повтори реалізуються і в явищах ампліфікації («стилістична фігура, що полягає в нагромадженні синонімів і взагалі слів із близьким значенням, однотипних висловів і синтаксичних конструкцій, однорідних членів речення і т. ін. або у висхідному повторенні слова, вислову, конструкції» [7, с. 22]). Так, ампліфікаційні ряди, у яких кожна одиниця має самостійне значення, служать для створення експресії. Мовні елементи, функціонуючи у взаємодії, емоційно підсилюють висловлену думку. Наприклад: Красо моя! Вкраӥночко моя!.. / Тебе люблю я всесвітом $і$ людством, / I соняхом у золотому сні, / I сивиною вченого-мислителя, / I на стерні горошком польовим (М. Вінграновський). Здрібніло-пестлива оказіональна форма Вкраїночко моя містить ознаку народнопісенності, ліричності. Цей оказіональний репрезентант виступає в наведеному тексті своєрідним інтенсифікатором зображеного (експліцитно й імпліцитно) глибокого почуття. Так Україну може назвати тільки той, хто відчуває до неї щиру і віддану любов.

Порівняймо ще: Північний вітер, нещадний вітер зірвався, / Спокійний дощик, класичний дощик зім'яв. / Крутнувся вихор, сипнув краплини, / I раптом тихо, напрочуд тихо зів'яв (В. Мельник). Використовуючи паронімічну атракцію, автор намагається зробити більш глибоким і значеннєво-образним повтор

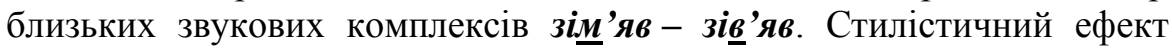
досягається саме завдяки мінімальному - в один приголосний розрізненню лексем.

Як засвідчив матеріал дослідження, повтор у поетичній мові задекларованого періоду виконує також асоціативно-образну функцію - сприяє виділенню типових чи оказіональних (креативних) ознак художнього образу, формує асоціативні поля. Порівняймо: $Я$ все прощу, бо нині я помер. I Я довго знав, що буду жити довще. / I чорний плащ облизує підошви, / I чорний місящь перерізав нерв (І. Андрусяк). Так, значення відтворюваної лексеми увиразнюються семантикою інших слів, які підсилюють іiі якості, асоціативнообразний потенціал конкретного слова, акцентують увагу на певному позначуваному ним об'єкті. Кожне окреме пряме чи переносне значення слова - це один із конкретних виявів мислення, сприймання людиною реалій життя. Як бачимо, символу чорний у наведеному сегменті підпорядковується весь мікроконтекст: чорний плащ, чорний 
місяць (лексема 3 семантикою чорного кольору розвинула переносне значення), які підсилюють вислів я помер.

Чорний колір асоціюється 3 негативними відчуттями, зі злими силами, нещастям, смертю, смутком, тривогою [1, с. 37] й виявляється в контексті через семантичну сполучуваність, яка сприяє увиразненню, розширенню та збагаченню меж зорового бачення, сприйняття й відображення дійсності.

Повтор, «співпрацюючи» 3 іншими стилістичними фігурами, виступає художнім засобом індивідуально-авторського освоєння дійсності, що дає змогу означити його ідіостилістичну функцію. Наприклад: Синій вітер у моӥм полоні / Чи у вітру у полоні я... / Синьовітер-вихор з Оболоні / Враз під себе хмари підім'яв... / Тільки усміх срібний на долоні, / Тільки долі срібна течія... / Синьоперо $y$ небеснім лоні / Пише липень літечка ім'я. / Синій вітер у моӥм полоні / Чи у вітру у полоні я... (А. Мойсієнко).

Кольорономінанти синій та срібний у наведеному текстовому фрагменті набувають філософського звучання - сприяють вираженню сутності людського життя на землі (синій колір - символ вічності, чистоти, правди та віри [1, с. 37], срібний - уособлює мудрість, талант, високу духовність [2, с. 576]). Для того, щоб актуалізувати унікальність життя, надати буденності неповторних (яскравих, незвичних) семантичних відтінків, уведені в контекст оказіоналізми (синьовітер-вихор, синьоперо). Так, використовуючи наявні в мові лексичні одиниці, митець прагне до оригінальності, свіжості оказіональних перенесень. Це досягається через нову й незвичну (креативну) референтну віднесеність, що ілюструє виключно суб'єктивне світобачення та світосприйняття, забезпечує несподівані поєднання лексем, їхніх значень. Стилістичний ефект індивідуалізмів, серед яких чимало складних утворень, підсилюється «свіжістю» їх внутрішніх форм (ексцентричний спосіб сполучуваності лінгвоодиниць підкреслює образність). Завдяки обраному типу словорозташування автор створює неповторний колорит оповіді, необхідний для реалізації ідейно-тематичного та художньо-образного задуму.

Отже, у системі лінгводомінант, наявних в українських поетичних текстах кінця XX - початку XXI століття, особливе місце належить повтору, який у «співдії» 3 іншими стрижневими стилістичними одиницями виступає важливим засобом образо- i текстотворення. Результати дослідження дають підстави стверджувати, що в мові означеного періоду ця стилістична фігура 
виконує такі основні функції: стратифікаційно-когерентну (сприяє структурній і семантичній цілісності тексту); емоційно-експресивну (інтенсифікує й увиразнює певні компоненти або й усе висловлення загалом); асоціативно-образну (сприяе виділенню окремих домінантних (часто - оказіональних) ознак художнього образу); ідіостилістичну (виступає художнім засобом індивідуальноавторського освоєння дійсності).

\section{Література}

1. Вовк О. В. Энциклопедия знаков и символов / О. В. Вовк. - М. : Вече, 2006. -528 с.

2. Жайворонок В. В. Знаки української етнокультури : [словник-довідник] / В. Жайворонок. - К. : Довіра, 2006. - 703 с.

3. Культура русской речи : [энциклопедический словарь-справочник] / [под ред. Л. Ю. Иванова, А. П. Сковородникова, Е. Н. Ширяева и др.]. - М. : Флинта : Наука, 2003. $-840 \mathrm{c}$.

4. Мацько Л. І. Стилістика української мови : [підручник] / Л. І. Мацько, О. М. Сидоренко, О. М. Мацько. - К. : Вища школа, 2003. - 462 с.

5. Селіванова О. О. Лінгвістична енциклопедія / О. О. Селіванова. - Полтава : Довкілля-К, 2010. - 844 с.

6. Синиця I. А. Лексичний повтор як засіб реалізації семантичної зв'язності тексту / І. А. Синиця // Мовознавство. - 1994. - № 2-3. - С. 56-60.

7. Українська мова : [енциклопедія] / [редкол. : Русанівський В. М., Тараненко О. О. (співголови), Зяблюк М. П. та ін.]. - [2-ге вид., випр. і доп.]. - К. : Вид-во «Укр. енцикл.» ім. М. Бажана, 2004. - 824 с. 